\title{
The Implementation of Additive Manufacturing in Industries Starting from Organizational Cultural Characteristics - A Review
}

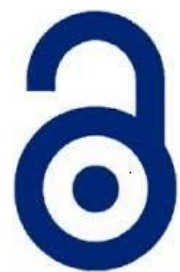 \\ Received: 26 February 2021 \\ Accepted: 20 April 2021 \\ Published: 01 October 2021 \\ Publisher: Deer Hill Publications \\ (C) 2021 The Author(s) \\ Creative Commons: CC BY 4.0
}

Almeida, J. F., Mourarias, M. N., Gerolamo, M. C. and Coelho, R. T.

\begin{abstract}
Additive Manufacturing (AM), widely known as 3D printing, is a fabrication process to build 3D parts layer by layer directly from a virtual CAD model. It is an innovative technology, with the potential to revolutionize the manufacturing industry completely. It is possible to manufacture complex shaped parts, shortening production sequence, reducing time to market and allowing mass customization. As one of Industry 4.0 nine pillars, AM has promoted an extensive number of researches. Some of them identify organizational culture as a leading factor affecting its implementation in industries. Like any change within companies, organizational culture can be a decisive factor for the successful implementation of AM. However, few studies have thoroughly explored the subject to find which set of cultural characteristics can guide the whole organization. This research identifies, through a systematic literature review (SLR) based on the PRISMA Protocol, which set of cultural characteristics can guide the transition from conventional to AM technology. The systematic literature review was capable of identifying a set of 41 cultural characteristics, which the company should present to implement AM successfully. Knowing which cultural characteristics can help AM implementation companies will increase their chances of succeeding when moving towards AM technologies within Industry 4.0.
\end{abstract}

Keywords: Additive Manufacturing, Organizational Culture, Innovation.

\section{INTRODUCTION}

New concepts, such as industry 4.0, are emerging bringing nine pillars: Big Data and Analytics; Autonomous Robots; Simulation; System Integration; Internet of Things (loT); Cyber security and Cyber Physical Systems (CPS); Cloud Computing; Augmented Reality and Additive Manufacturing (AM). To couple with that, existing production systems will have to be transformed (Vaidya, Ambad, \& Bhosle, 2018). AM, for example, is significantly changing the current production systems, presenting potential to transform the entire global market. With AM many companies can move from a concept of mass production to the production of customized products, in smaller batches, made to order or even diversify its existing products.

Many investigations on several aspects of AM have been carried out. For example, Bourell et al. (2017); Ngo, Kashani, Imbalzano, Nguyen, \& Hui (2018) and Singh, Ramakrishna, \& Singh (2017) addressed materials used in AM processes, Biamino et al. (2011); Casati, Lemke, \& Vedani (2016); DebRoy et al. (2018); Gaytan et al. (2010); Gu, Meiners, Wissenbach, \& Poprawe (2012); Khairallah, Anderson, Rubenchik, \& King (2017); Li, Zhou, Brochu, Provatas, \& Zhao (2020); and Vrancken, Thijs, Kruth, \& Van Humbeeck (2012), analysed various existing AM technologies, microstructures of the materials produced, as well as their mechanical properties. Despite the enormous expectations created around AM technology and its innovative effects in several sectors, the current literature is more concentrated on engineering, with few contributions related to the impacts suffered by industries regarding its organizational aspects (Savolainen \& Collan, 2020). In such context, the organizational culture must be a factor to consider, since several studies indicate that it is one of the main responsible for improvements in performance (Cameron, Quinn, DeGraff, \& Thakor, 2006) and excellence achievements (Schein, 1984).

Most people responsible for industrial organizations normally fear changes, such as, moving towards implementing AM as a manufacturing technology. The impact of that manoeuvre on personnel must be considered

Almeida, J. F. 囚, Mourarias, M. N., Gerolamo, M. C. and Coelho, R. T.

Department of Production Engineering,

São Carlos School of Engineering,

University of São Paulo,

Av. Trabalhador São-Carlense, 400 - Parque Arnold Schimidt, São Carlos, 13566-590, Brazil

E-mail: julia.f.almeida@usp.br

Reference: Almeida et al. (2021). The Implementation of Additive Manufacturing in Industries Starting from Organizational Cultural Characteristics - A Review. International Journal of Engineering Materials and Manufacture, 6(4) $242-258$. 
(Dietrich, Kenworthy, \& Cudney, 2019). To lead the necessary changes in a company Dietrich, Kenworthy, \& Cudney (2019) developed the eight-step model presented by Kotter (1996), to promote a new approach in the company culture. Through their experiences, those authors highlighted that "adopting and anchoring AM change within the company culture is harder than it may seem". If the manager underestimates the culture change requirements necessary to implement $A M$ in the organization, even when hiring an $A M$ expert, the implementation process could lead to failure (Dietrich et al., 2019).

This research work aims at identifying a set of cultural characteristics, through a systematic literature review (SLR) based on the PRISMA Protocol, which can lead to a successful implementation of AM in many companies. The methodology resulted in a large set of identified cultural characteristics, which were discussed and analysed. The paper is organized as follows: Section 2 contains the background of additive manufacturing and organizational culture. Section 3 presents the research methodology. In section 4, the results are presented and discussed, and section 5 presents the conclusion.

\section{BACKGROUNDS}

\subsection{Additive Manufacturing}

Additive Manufacturing (AM) was a technology, initially named as Rapid Prototyping, that today is widely known as 3D printing (Gibson, Rosen, \& Stucker, 2015). The ASTM F2792 - 10 (2010) standard defines AM as "process of joining materials to make objects directly from a CAD (computer aided design) data, usually layer upon layer, as opposed to subtractive manufacturing techniques (machining, for example)". AM technologies can be divided into seven categories: Binder jetting; Directed energy deposition (DED); Material extrusion; Material jetting; Powder-bed fusion (PBF); Sheet lamination; e Vat photopolymerization (American Society for Testing and Materials, 2012), each one of them with a particular way of building parts, but with se same concept as defined by the standard.

The AM manufacturing process is performed in a series of steps that vary according to the AM technology and equipment used. Generally, the steps are: design in a CAD software; Conversion to STL; Transfer to AM Machine and STL File Manipulation; Machine Setup; Build; Removal; Post-processing; and Application (Gibson et al., 2015). To evaluate the viability of using AM, several factors must be analysed to define the most suitable manufacturing process. Depending on the level of complexity, a traditional process would take too long or technologically it would be unsuitable for the whole part. Additional factors are the level of customization, the size of a production batch, i.e., the production volume, what the costs would be, the production rate, etc. (Bland \& Conner, 2015).

The pace of adoption AM in each sector depends on the characteristics of the company, level of regulation and characteristics of the leaders in relation to innovation acceptance and risk assuming (Saunders, 2018). Renishaw, a company that works with the PBF process, proposed a model to show the different levels of AM adoption: Rapid prototypes \& tooling; direct part replacement; part consolidation; and DfAM (Design for AM) optimized. The first level is the starting point for most companies to implement $A M$ in their production system. At the second level, the process is changed to AM, eliminating traditional production sequences and making the supply chain more agile (Saunders, 2018). The third level is the first in which parts are really modified and AM starts to gain advantages thanks to its ability to produce complex, lighter shapes and with the possibility of small customizations. There is also the possibility of replacing several parts, previously assembled, with a single one, produced in a shorter period of time. Finally, the fourth level, offers full use of AM technology, by which everything can be improved, modified by topological optimization making the part lighter and more efficient, as well as the whole product. Additionally, AM allows mass customization without increasing cost and time (Saunders, 2019). To achieve the highest levels, it will be required more maturity inside the organization and a greater commitment by the entire company to the development and qualification of new products, as well as with all the difficulties of a new manufacturing process. The benefits tend to increase and the more disruptive the technology incorporated into products, the more valuable they become (Saunders, 2018). Each company must analyse which stage it is in, and follow the steps to improve its product using AM.

\subsection{Organizational Culture}

Organizational Culture, as defined by Schein (1984), "is the pattern of basic assumptions that a given group has invented, discovered, or developed in learning to cope with its problems of external adaptation and internal integration, and that have worked well enough to be considered valid". Several recent works around the world point, through empirical evidence, to the influence of organizational culture on the overall performance of most organizations. Other works, moreover, point to the influence of organizational culture on companies innovation (Stacho, Potkány, Stachová, \& Marcineková, 2016). In this context, to develop innovation, some studies indicate that companies need "knowledge, new skills, flexible working conditions; organizational climate and culture that support the development of innovations and the innovation potential of each individual” (Vnoučková \& Urbancová, 2020). Cultural Characteristics (CC), such as, flexibility and support for positively change, influence creativity and, consequently, innovation within a company (Shahzad, Xiu, \& Shahbaz, 2017). As a consequence, some cultural characteristics need to be developed, such as, organizational values and their alignment with those of employees, team motivation and development, selection of employees and their commitment to innovation. (Carro-Suárez, Sarmiento-Paredes, \& Rosano-Ortega, $2017 \mathrm{Yu} \&$ Shih, 2018) highlight that organizational culture influences the sustainability of a business, and the factors that most affect the sustainability, would be the mission, the vision, the 
presence of a goal and its consistency. Employees should also be involved in knowing and meeting customer needs, learning new skills and creating changes (Ali Taha, Sirkova, \& Ferencova, 2016; Vargas Halabi, Mora Esquivel, \& Ortiz Acuña, 2015). Cross-functional cooperation, with teams from different departments and different sets of knowledge and skills, facilitates the processes of communication, information sharing and cooperation, influencing the company success (Lee, Chong, \& Ramayah, 2018).

Many of these Cultural Characteristics covered by the publications are derived from models such as Competing Values Framework by Quinn \& Rohrbaugh (1983), Organizational Culture Assessment Instrument (OCAl) by Cameron, K. S.; Quinn (1999); OCP Model (Organizational Culture Profile) by O'Reilly, Chatman, \& Caldwell (1991); Model by Hofstede (2001); Cooke, R. A.; Lafferty (1995) in Organizational Culture Index (OCI) (1995). Quinn and Rohrbaugh's CVF (Competing Values Framework) and Organizational Culture Assessment Instrument (OCAl), which define clan/collaboration, hierarchical/control, adhocracy/creation and market/competition culture, are the ones that most appeared in the publications.

Organizational learning, which is adept at creating, acquiring and transferring knowledge and modifying organizational behaviour to reflect new knowledge and perceptions (Garvin, 1993), also impacts positively the results of innovations in organizations, (Chang, Liao, \& Wu, 2017; Chatterjee, Pereira, \& Bates, 2018; Leal-Rodríguez, Eldridge, Ariza-Montes, \& Morales-Fernández, 2019; Mardiana \& Tjakratmadja, 2019; Rezaei, Allameh, \& Ansari, 2018; Tang \& Yeh, 2015) with knowledge transfer being the mediator between organizational culture and the capacity for innovation (Liao, Hu, Chen, \& Lin, 2015). The most flexible and supportive organizations (Liao et al., 2015), such as those with an adhocracy or clan culture, are those with the highest rates of knowledge/learning transfer (Chatterjee et al., 2018), unlike cultures market and hierarchical (Leal-Rodríguez et al., 2019; Rezaei et al., 2018). However, during crises, the hierarchical culture can be great at offering support due to its strong leadership structure and rules that helps maintain the organization's cohesion (Mardiana \& Tjakratmadja, 2019). With regard to organizational agility, the adhocracy culture and clan stand out, since these cultures are more flexible and adaptive, the latter to a lesser extent. As for the hierarchical culture, which is expected to have a negative effect in changes it can have a positive effect, because the stability, control and order promoted by it can be beneficial in scenarios of crises and uncertainties (Felipe, Roldán, \& Leal-Rodríguez, 2017), including the presence of control systems can positively influence the management of innovations (Alharbi, Jamil, Mahmood, \& Shaharoun, 2019).

Leadership can also be one of the factors that influence the innovative behaviour of employees. Leaders must: stimulate innovation in employees, monitor the innovation process, motivate employees to be creative, be a leader in the implementation of innovative processes, planning and starting the innovation process (Szczepańska-Woszczyna, 2015). Regarding the development of new products, the profiles of adhocracy culture and market are the ones that stand out the most. The adhocracy in the initial and implementation phases of a product, and the market only in the implementation phase (Naranjo-Valencia, Jimenez-Jimenez, \& Sanz-Valle, 2017a).

Finally, although there are a large number of studies on organizational culture, there is still no common and integrated approach among these diverse works, which makes the definition of organizational culture and how to measure culture still imprecise. New work should go against this, avoiding the fragmentation of what is already known about organizational culture (Chatman \& O'Reilly, 2016).

\subsection{AM and Organizational Culture}

Companies with business models whose values focus on efficiency, usually, do not favour innovation (Hock, Clauss, \& Schulz, 2016), unlike those that adopt flexibility in operations (Wu, Huang, Huang, \& Du, 2019). Exploratory studies (Alexe \& Alexe (2018) point out that companies related to technology give more importance to aspects favouring innovative environments compared to those of heavy industry (machines for example). (Bercea, Lakatos, $\&$ Bacali, 2019) find that organizational culture of non-profit companies carries greater importance to innovation than those seeking for non-profit.

Although managers believe that the cultural aspect is important for the success of the business and that innovation can bring competitive advantages (Dorin MAIER, Robert BUMBAC, Cristian ILIE, \& Andreea MAIER, 2019), leaders must clearly understand how the available organizational behaviour can influence the company business (Krupskyi \& Kuzmytska, 2020). In a scenario of massive digitalization and industry 4.0 (14.0), culture impacts the success of these initiatives (Sieber, 2019; Ziaei Nafchi, Mohelská, \& Maresova, 2019), as it determines the development and survival of an organization (Pietruszka-Ortyl, 2019). Even if some change takes months or years, making a culture more innovative is extremely important for organizations (Bendak, Shikhli, \& Abdel-Razek, 2020) in a scenario of emerging technologies such as additive manufacturing (3D printing), robotics, among others (Chang et al., 2017).

Although it has great potential innovation, AM present several barriers to be implemented in companies. Those barriers can be classified into eight distinguished classes: Organizational, Educational, Technological, Financial, Quality; project, Regulations, and Environmental (Almeida, 2021). These barriers have been extensively studied by researchers, but cultural characteristics of companies are another subject specifically related with people living and pushing the whole organization. A company culture can encourage or repress innovations and changes. Companies must work to develop a culture strongly supporting innovative behaviour in employees (Stacho et al., 2016). One innovative and disruptive technology, such as AM, will have a great impact on most companies, especially in their organizational culture, which will certainly go through significant changes in the near future. 


\section{METHODOLOGIES}

For the identification of Cultural Characteristics that may affect the adoption of innovative practices, such as AM, a SLR was carried out supported by the PRISMA protocol (McInnes et al., 2018; Stewart et al., 2015). To guide this review, the research question was defined: $Q 1$ - What Cultural Characteristics/factors affect the adoption of innovative technologies such as AM? To answer this question, the Scopus and Web of Science (WoS) databases were used for search. Table 1 presents the terms and a search string.

Publications from Journals and from congresses were used, in 3 languages: English, Portuguese and Spanish. Thus 217 publications were selected after eliminating duplicates. Title, summary and keywords of these documents were read identifying only those related to the research question (Q1), remaining 57 . Those were fully read and 35 revealed clearly related with Cultural Characteristics aspects that affect the adoption of innovative initiatives, such as, AM. Figure 1 schematically shows the phases (identification, screening, eligibility and inclusion) and the results of the SLR conducted at the present work.

Table 1: Search string

\begin{tabular}{|c|c|c|}
\hline Data Base & Terms and Operators & String \\
\hline Scopus & $\begin{array}{l}\text { "Organizational } \\
\text { Culture" and } \\
\text { "Innovation" }\end{array}$ & $\begin{array}{l}\text { Title (“Organizational Culture”) Title-abs-key(“Innovation”) } \\
\text { Limit-to (Subarea, "Business" OR “Engineering” OR “Decision } \\
\text { Sciences" OR “Multidisciplinary”) } \\
\text { Limit-to (Pub year, } 2015 \text { to 2020) } \\
\text { Limit-to (Language, "English” OR “Spanish” OR “Portuguese”) }\end{array}$ \\
\hline
\end{tabular}

Title (“Organizational Culture”) Topic(“Innovation”) Limit-to (Category, Management OR Business OR Engineering

$\begin{array}{ll}\text { Web of Science } & \text { "Organizational } \\ \text { (WoS) } & \text { Culture" and } \\ & \text { "Innovation" }\end{array}$
Environmental OR Economics OR Environmental Studies OR (WoS) "Innovation" Multidisciplinary Science OR Engineering Manufacturing OR Social Work OR Engineering Industrial OR Environmental Science OR Business Finance OR Engineering Multidisciplinary)

Limit-to (Language, English OR Spanish OR “Portuguese”)

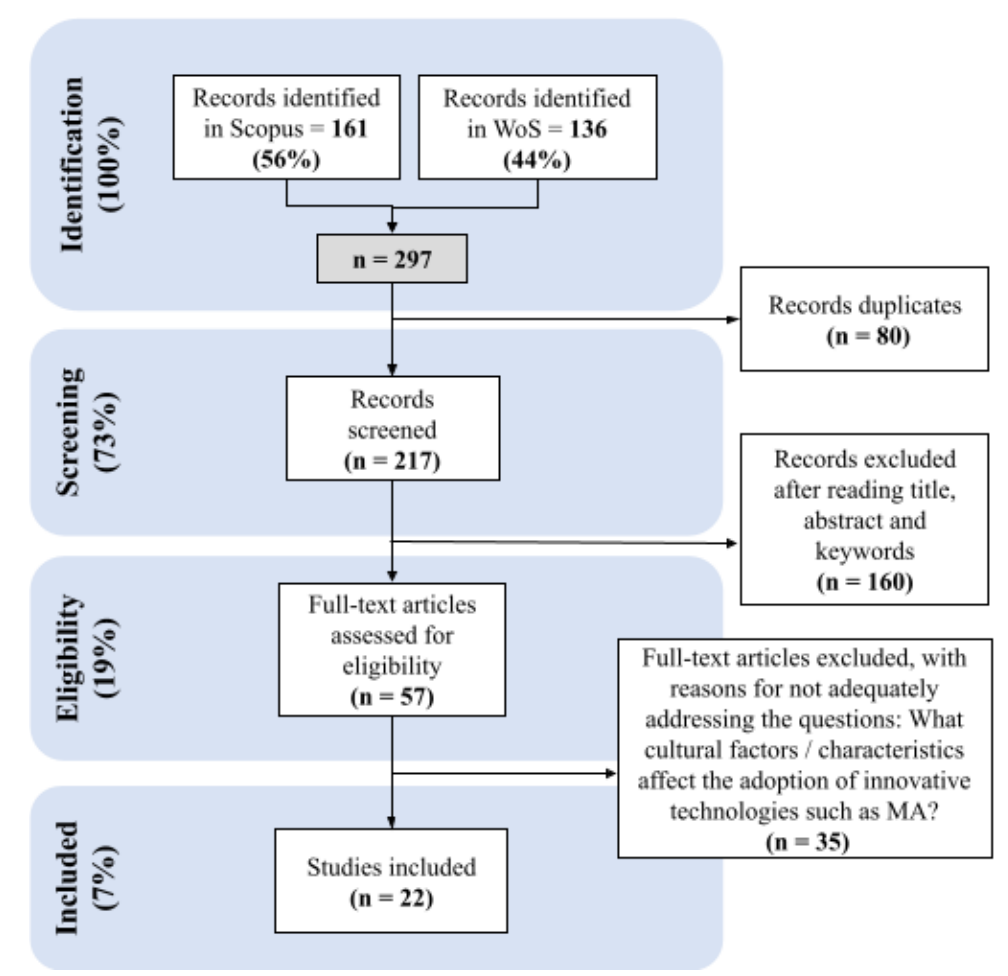

Figure 1: The phases of the SLR through the PRISM PROTOCOL of the research 4 RESULTS AND DISCUSSIONS

Table 2 shows a list of the cultural characteristics affecting the adoption of innovative technologies, such as AM, in organization, identified after SLR. In addition, presents the type of analysis performed by the authors, the sample size 
and the country where these analyses occurred. Generally, all selected publications, after SLR, presented the analysis of some kind of cultural characteristics, but only those explicitly refereeing to them were inserted in Table 2 (22 out of the 35). The results empirically demonstrate the impact of these cultural characteristics on the organizations.

Figure 2 presents a map with a distribution of the papers by quantities and countries. It is possible to notice a variety of countries, with emphasis on Spain, Czech Republic and the Slovak Republic with two publications each one. Figure 3 shows the type of analysis used in the samples to arrive at the conclusions. There is predominance of Case Studies (6) and Regression (5).

After the extraction of the characteristics / factors, these were analysed and the similar ones were merged or eliminated. Table 3 presents the synthesis of the Cultural Characteristics / Factors in alphabetical order, its definition and the responsible (organization, leader, team or employee). In total, 41 cultural characteristics were obtained in the literature. Some of the definitions were not found in the original articles, so a definition is presented by the authors.

The authors first propose to develop the organization responsibility characteristics, which has more resources to develop them, and later develop the leaders, the team and the employee's characteristics. 
Table 2: Cultural characteristics cited by the papers

\begin{tabular}{|c|c|c|c|c|c|}
\hline $\mathrm{N}^{\mathrm{e}}$ & Papers & Cultural characteristics/Factors & Type of Analysis & Sample & Country \\
\hline 1 & $\begin{array}{l}\text { (Vargas Halabi et al., } \\
\text { 2015) }\end{array}$ & $\begin{array}{l}\text { Openness and ability to absorb new ideas; emphasis on creativity; promoting risk- } \\
\text { taking; and freedom to express opinions. }\end{array}$ & Case Study & $\begin{array}{l}\text { Five company } \\
\text { managers }\end{array}$ & $\begin{array}{l}\text { Costa } \\
\text { Rica }\end{array}$ \\
\hline 2 & (Tang \& Yeh, 2015) & Support, creative, bureaucratic, and efficiency-driven cultures & $\begin{array}{l}\text { Structural Equation } \\
\text { Modelling (SEM) }\end{array}$ & $\begin{array}{l}398 \text { responses } \\
\text { from public } \\
\text { companies }\end{array}$ & Taiwan \\
\hline 3 & (Hock et al., 2016) & $\begin{array}{c}\text { Speed, quality and competence, success, innovation and flexibility, openness of } \\
\text { internal communication, interfunctional cooperation (Homburg/Pflesser, 2000, as } \\
\text { cited in Hock et al., 2016) }\end{array}$ & $\begin{array}{l}\text { Structural Equation } \\
\text { Modelling (SEM) }\end{array}$ & $\begin{array}{l}305 \text { small and } \\
\text { medium-sized } \\
\text { electronics } \\
\text { industry }\end{array}$ & Germany \\
\hline 4 & (Stacho et al., 2016) & Open communication between subordinates and supervisors & Case Study & 3 companies & $\begin{array}{l}\text { Slovak } \\
\text { Republic }\end{array}$ \\
\hline 5 & (Ali Taha et al., 2016) & $\begin{array}{l}\text { Plsek, } 1997 \text { as cited in (Ali Taha et al. (2016) identifies five factors that drive the need } \\
\text { for creativity and innovation in organizations today: (1) superior long-term financial } \\
\text { performance is associated with innovation; ( } 2 \text { ) Customers are demanding innovation; } \\
\text { (3) competitors are getting better at copying past innovations; (4) new technologies } \\
\text { enable innovation; and (5) what used to work no longer works. }\end{array}$ & Regression & $\begin{array}{c}184 \\
\text { organizations }\end{array}$ & $\begin{array}{l}\text { Slovak } \\
\text { Republic }\end{array}$ \\
\hline 6 & $\begin{array}{l}\text { (Carro-Suárez et al., } \\
\text { 2017) }\end{array}$ & Mission, involvement, consistency and adaptability & Regression & $\begin{array}{l}1 \text { Ceramics } \\
\text { industry }\end{array}$ & Mexico \\
\hline 7 & (Shahzad et al., 2017) & $\begin{array}{c}\text { External orientation, Organizational climate, Flexibility, support to change, Teamwork } \\
\text { and Employee empowerment }\end{array}$ & Regression & $\begin{array}{l}215 \text { responses } \\
\text { from } 29 \\
\text { software } \\
\text { companies }\end{array}$ & Pakistan \\
\hline 8 & $\begin{array}{l}\text { (Naranjo-Valencia, } \\
\text { Jimenez-Jimenez, \& } \\
\text { Sanz-Valle, 2017b) }\end{array}$ & $\begin{array}{c}\text { Characteristics of CVF cultures by Quinn \& Rohrbaugh (1983) and Organizational } \\
\text { Culture Assessment Instrument (OCAl) by Cameron, K. S.; Quinn (1999): Clan, market, } \\
\text { adhocracy and hierarchical: Evaluation by external entities } \\
\text { Communication and Information Management; Conflict / Cohesion; Control; Crowth; } \\
\text { Efficiency; Emphasis on Training \& Development; Stability; Flexibility / Adaptation; } \\
\text { Moral; Planning and Coal Setting; Productivity; Readiness; Quality; Use of the } \\
\text { environment / Acquisition of resources }\end{array}$ & $\begin{array}{c}\text { Structural Equation } \\
\text { Modelling (SEM) }\end{array}$ & $\begin{array}{l}253 \text { responses } \\
\text { from } 253 \\
\text { Spanish } \\
\text { manufacturing } \\
\text { companies }\end{array}$ & Spain \\
\hline
\end{tabular}


Characteristics of CVF cultures by Quinn \& Rohrbaugh (1983) and Organizational Culture Assessment Instrument (OCAl) by Cameron, K. S.; Quinn (1999): Clan, market, adhocracy and hierarchical: Evaluation by external entities

9 (Naranjo-Valencia et Communication and Information Management; Conflict / Cohesion; Control; Growth al., 2017a) Efficiency; Emphasis on Training \& Development; Stability; Flexibility / Adaptation; Moral; Planning and Goal Setting; Productivity; Readiness; Quality; Use of the environment / Acquisition of resources

Characteristics of CVF cultures by Quinn \& Rohrbaugh (1983) and Organizational Culture Assessment Instrument (OCAl) by Cameron, K. S.; Quinn (1999): Clan, market, adhocracy and hierarchical: Evaluation by external entities

10 (Rezaei et al., 2018) Communication and Information Management; Conflict / Cohesion; Control; Growth; Efficiency; Emphasis on Training \& Development; Stability; Flexibility / Adaptation; Moral; Planning and Goal Setting; Productivity; Readiness; Quality; Use of the environment / Acquisition of resources

Regression 200 Spanish companies

There are 16 transfer factors that are divided into four groups: trainee characteristics, There are 16 transfer factors that are divided into four groups: trainee characteristics,
motivation, work environment and capacity. Holton (1996), as cited in Chatterjee et al. (2018) describes the transfer factors related to the work environment as being composed of seven constructs, namely, performance coaching, supervisor support, supervisor sanctions, peer support, resistance to change, positive personal results and negative personal results.

11 (Chatterjee et al., 2018)

133 responses

from industrial

Structural Equation

Modelling (SEM)

technology

based

companies and

start-ups
Iran

159 responses,

$98 \%$ from the

private sector

and $2 \%$ from

the government

Innovation, results orientation, respect for people, team orientation, stability, aggressiveness and attention to detail 


\begin{tabular}{|c|c|c|c|c|c|}
\hline 16 & (Pietruszka-Ortyl, 2019) & $\begin{array}{c}\text { Great freedom of action, teamwork and efficiency in communication, openness to } \\
\text { changes and proactive attitudes. }\end{array}$ & Theoretical & 238 replies & Poland \\
\hline 17 & (Sieber, 2019) & $\begin{array}{c}\text { Connection, Non-linearity, Customer centricity, Innovative, Rapid experimenting, } \\
\text { Risk-taking, Status-quo questioning, Autonomy, Bureaucratic, Collaboration, Control, } \\
\text { Coordination, Cross-boundary, Cross-functionality, Discipline, Hierarchy, Participation, } \\
\text { Self-organization, Soft-skills providing, Talent investment, appreciation, Flexibility, } \\
\text { Generativity, Internal communication, Mindset orientation, Openness, Subculture, } \\
\text { Success awarding, Supportive }\end{array}$ & Review & 9 articles & - \\
\hline 18 & $\begin{array}{l}\text { (Ziaei Nafchi et al., } \\
\text { 2019) }\end{array}$ & $\begin{array}{l}\text { Organizational Culture Index }(\mathrm{OCl}) \text { by Wallach, } 1983 \text { as cited in Ziaei Nafchi et al. } \\
\text { (2019): risk taking, collaborative, hierarchical, procedural, relationship- } \\
\text { oriented, results-oriented, creative, encouraging, sociable, structure, pressurized, } \\
\text { ordered, stimulating, regulated, established - solid, cautious, trusting, } \\
\text { driving and power-oriented and Hofstede's Dimensions (2001): collectivism, long- } \\
\text { term orientation, low distance of power, women's value, low degree of avoidance of } \\
\text { uncertainty, short-term orientation, high distance of power, males values, } \\
\text { individualism, a high degree of uncertainty. }\end{array}$ & Theoretical & - & $\begin{array}{l}\text { Czech } \\
\text { Republic }\end{array}$ \\
\hline 19 & (Bendak et al., 2020) & $\begin{array}{c}\text { Creativity, freedom, teamwork and risk-taking, such as availability of resources, } \\
\text { customer orientation, employee participation, cooperation, guidance for continuous } \\
\text { learning and flexibility. }\end{array}$ & Theoretical & $\begin{array}{l}3 \text { midsize } \\
\text { companies in } \\
\text { Abu Dhabi City, } \\
\text { United }\end{array}$ & $\begin{array}{l}\text { United } \\
\text { Arab } \\
\text { Emirates }\end{array}$ \\
\hline 20 & $\begin{array}{c}\text { (Krupskyi \& Kuzmytska, } \\
\text { 2020) }\end{array}$ & 5 strategies: visionary, classic, adaptive, modelling, renewal & Case study & 561 employees & USA \\
\hline 21 & $\begin{array}{l}\text { (Miletić, Stanojević, } \\
\text { Jovanović, Radivojević, } \\
\text { \& Conić, 2020) }\end{array}$ & $\begin{array}{l}\text { Collectivism, long-term orientation, low distance of power, women's value, low } \\
\text { degree of avoidance of uncertainty, short-term orientation, high distance of power, } \\
\text { males' values, individualism, a high degree of uncertainty (Hofstede Dimensions) }\end{array}$ & $\begin{array}{l}\text { Analytic Hierarchy } \\
\text { Process (AHP) }\end{array}$ & $\begin{array}{l}\text { Textile } \\
\text { Companies }\end{array}$ & Serbia \\
\hline 22 & $\begin{array}{l}\text { (Parolin, Bonfim, } \\
\text { Segatto, \& Espindola, } \\
\text { 2020) }\end{array}$ & $\begin{array}{l}\text { Flexible organizational structure; successful organizational culture based on technology } \\
\text { and innovation; cohesion among its members; strategic management of human } \\
\text { resources for the valorisation of people; decision-making process aiming at a clear } \\
\text { orientation to the market, which adds value to R\&D results (Lau \& Ngo, 2004; Tidd et } \\
\text { al., 2008, as cited in Parolin, Bonfim, Segatto, \& Espindola, 2020) }\end{array}$ & Case Study & $\begin{array}{l}324 \text { respondents } \\
\text { from } 58 \text { large } \\
\text { companies and } \\
41 \text { public and } \\
\text { private research } \\
\text { institutes. }\end{array}$ & Brazil \\
\hline
\end{tabular}




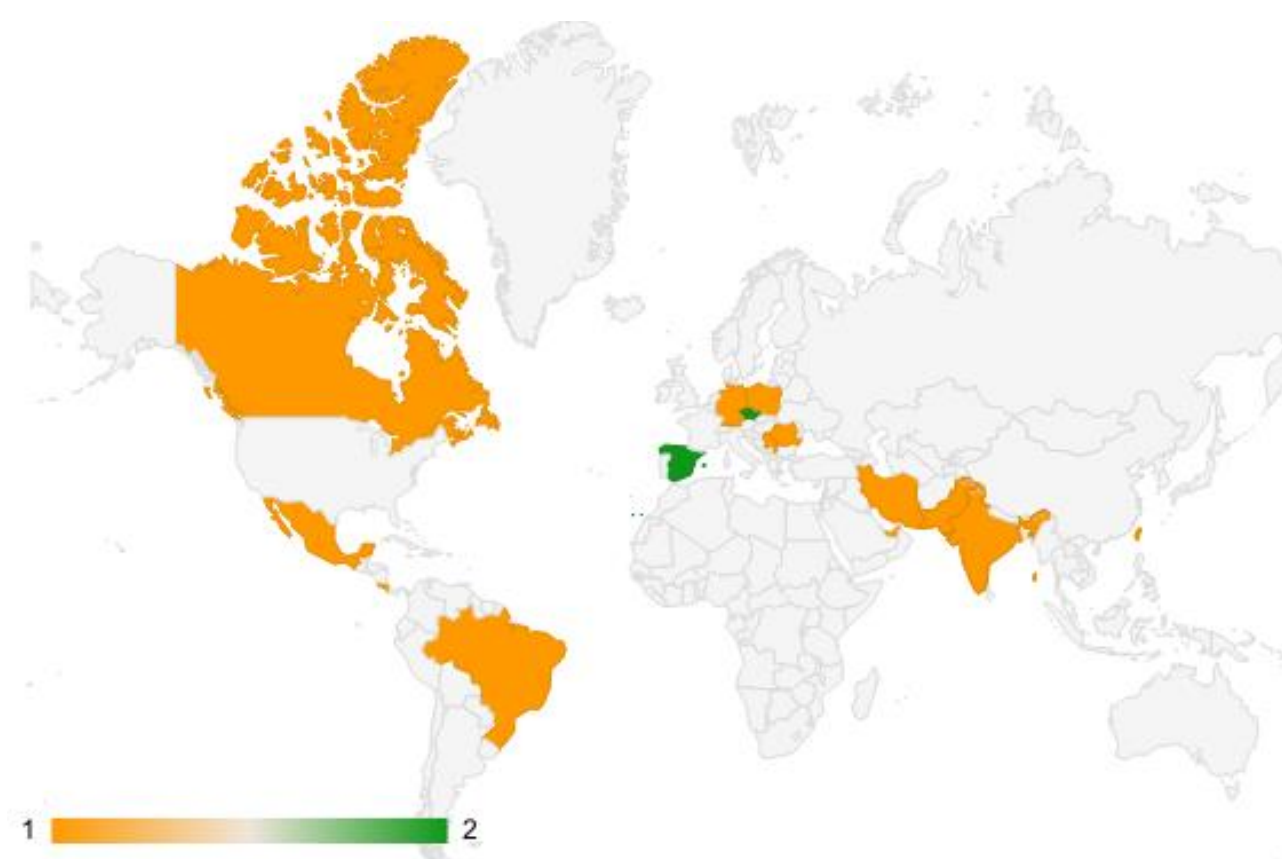

Figure 2: Paper by quantities and countries

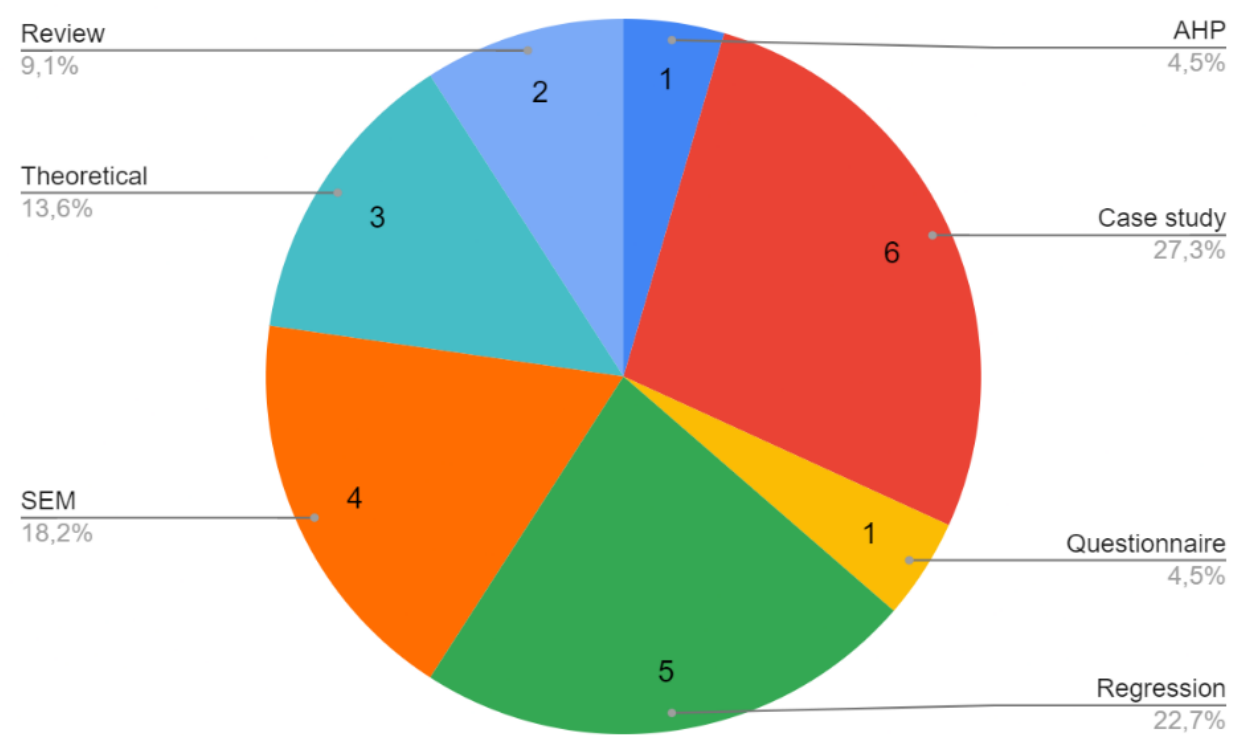

Figure 3: Type of Analysis

Table 3: Synthesis of Cultural Characteristics extracted from literature

\begin{tabular}{cclc}
\hline $\mathrm{N}^{\mathbf{2}}$ & Cultural Characteristics & \multicolumn{1}{c}{ Definition } & Responsible \\
\hline 1 & Adaptability & $\begin{array}{l}\text { "The extent to which organizations focus } \\
\text { on learning from competitors and } \\
\text { customers and are able to change" } \\
\text { (Chatman \& O'Reilly, 2016). }\end{array}$ & Organization \\
\hline 2 & Aggressiveness & $\begin{array}{l}\text { "Determination to win or succeed, and the } \\
\text { use of forceful action to do this" } \\
\text { (Cambridge English Dictionary, 2021a). }\end{array}$ & Organization \\
\hline 3 & Collectivism & $\begin{array}{l}\text { "Is characterized by a focus on shared } \\
\text { objectives, interchangeable interests, and }\end{array}$ & Team \\
\hline
\end{tabular}




\begin{tabular}{|c|c|c|c|}
\hline $\mathrm{N}^{\circ}$ & Cultural Characteristics & Definition & Responsible \\
\hline & & $\begin{array}{l}\text { commonalities among in-group members" } \\
\text { (Triandis, 1995, as cited in Chatman \& } \\
\text { O'Reilly, 2016). }\end{array}$ & \\
\hline 4 & Commitment & $\begin{array}{l}\text { "Willingness to give your time and energy } \\
\text { to a job, activity, or something that you } \\
\text { believe in"(Cambridge English Dictionary, } \\
2021 b) \text {."Ensures everyone's participation } \\
\text { in creating anything new (Chatterjee et al., } \\
\text { 2018). }\end{array}$ & Employee \\
\hline 5 & Communication & $\begin{array}{l}\text { "The process of sharing information, } \\
\text { especially when this increases } \\
\text { understanding between people or groups" } \\
\text { (Cambridge English Dictionary, 2021c). }\end{array}$ & Organization/ Team \\
\hline 6 & Competence & $\begin{array}{l}\text { "Shows the prominence of having } \\
\text { competent skills, knowledge and } \\
\text { experience of the employees in performing } \\
\text { the task-at-hand (Lee et al., 2018)". }\end{array}$ & Employee \\
\hline 7 & $\begin{array}{l}\text { Connection to company } \\
\text { values }\end{array}$ & $\begin{array}{l}\text { "The state of being related to someone or } \\
\text { something else"(Cambridge English } \\
\text { Dictionary, 2021d), in this case, related to } \\
\text { the company's values. }\end{array}$ & Organization \\
\hline 8 & Consistency & $\begin{array}{l}\text { "Internal consistency is based on whether } \\
\text { an organization has espoused a set of } \\
\text { values that are consistent and to which } \\
\text { they visibly adhere, including } \\
\text { interdepartmental coordination" (Chatman } \\
\text { \& O'Reilly, 2016). }\end{array}$ & Organization \\
\hline 9 & Continuous learning & $\begin{array}{l}\text { "The process of learning new skills and } \\
\text { knowledge on an on-going basis" (Valamis, } \\
\text { 2019). }\end{array}$ & Employee \\
\hline 10 & Control of activities & $\begin{array}{l}\text { "Organizations require control systems that } \\
\text { define goals, assess variation from these, } \\
\text { and provide feedback to individuals so } \\
\text { they can adjust and coordinate their } \\
\text { activities" (Chatman \& O'Reilly, 2016). }\end{array}$ & Leader \\
\hline 11 & Cooperation & $\begin{array}{l}\text { "The process of working with another } \\
\text { company, organization, or country in } \\
\text { order to achieve something"(Cambridge } \\
\text { English Dictionary, 2021e). }\end{array}$ & Organization/Team \\
\hline 12 & Creativity & $\begin{array}{l}\text { "A complex, cognitive process that } \\
\text { involves finding and developing solutions } \\
\text { to novel, ill-defined problems that will } \\
\text { enhance the organization in the form of its } \\
\text { products, services, processes, and } \\
\text { procedures" (Mumford and Gustafson, } \\
\text { 1988, as cited in Ali Taha et al., 2016). }\end{array}$ & Team/Employee \\
\hline 13 & Customer-focused & $\begin{array}{l}\text { "Paying great attention to the needs and } \\
\text { opinions of customers" (Cambridge English } \\
\text { Dictionary, 2021f) }\end{array}$ & Organization \\
\hline 14 & Discipline & $\begin{array}{l}\text { "The ability to control yourself or other } \\
\text { people, even in difficult situations" } \\
\text { (Cambridge English Dictionary, 2021g) }\end{array}$ & Leader/Team/Employee \\
\hline 15 & Efficiency & $\begin{array}{l}\text { "A situation in which a person, company, } \\
\text { factory, etc. uses resources such as time, } \\
\text { materials, or labour well, without wasting } \\
\text { any"(Cambridge English Dictionary, } \\
2021 \mathrm{~h}) \text {. }\end{array}$ & Organization \\
\hline 16 & Empower employees & $\begin{array}{l}\text { "The ways in which organizations provide } \\
\text { their employees with a certain degree of }\end{array}$ & Leader \\
\hline
\end{tabular}




\begin{tabular}{|c|c|c|c|}
\hline $\mathrm{N}^{\circ}$ & Cultural Characteristics & Definition & Responsible \\
\hline & & $\begin{array}{l}\text { autonomy and control in their day-to-day } \\
\text { activities" (ASQ, 2021). }\end{array}$ & \\
\hline 17 & Encouragement & $\begin{array}{l}\text { "Words or behaviour that give someone } \\
\text { confidence to do something"(Cambridge } \\
\text { English Dictionary, 2021i). }\end{array}$ & Leader \\
\hline 18 & Flexibility & $\begin{array}{l}\text { "The ability to change or be changed easily } \\
\text { according to the situation" (Cambridge } \\
\text { English Dictionary, 2021j). }\end{array}$ & Organization \\
\hline 19 & Innovation & $\begin{array}{l}\text { "The successful development of new ideas } \\
\text { or method, or the use of new ideas and } \\
\text { methods" (McLean, 2005, as cited in Ali } \\
\text { Taha et al., 2016;(Cambridge English } \\
\text { Dictionary, 2021k). }\end{array}$ & Organization \\
\hline 20 & Leadership support & $\begin{array}{l}\text { "Encourage someone or something because } \\
\text { you want him or her to succeed } \\
\text { (Cambridge English Dictionary, 2021v), in } \\
\text { that case, provided by the leadership. }\end{array}$ & Leader \\
\hline 21 & Low power distance & $\begin{array}{l}\text { This dimension defines how much a society } \\
\text { accepts the unequal distribution of power } \\
\text { (Hofstede, 2001) }\end{array}$ & Organization \\
\hline 22 & Motivation & $\begin{array}{l}\text { "Willingness to do something, or } \\
\text { something that causes such willingness" } \\
\text { (Cambridge English Dictionary, 2021m). }\end{array}$ & Employee \\
\hline 23 & Multifunctional teams & $\begin{array}{l}\text { "It is a team composed of people with the } \\
\text { different skills required to complete the } \\
\text { job" (Ramiro, 2018). }\end{array}$ & Team \\
\hline 24 & Openness to new ideas & $\begin{array}{l}\text { "The quality of being able to think about, } \\
\text { accept or listen to different ideas or } \\
\text { people"(Oxford Advanced Learner's } \\
\text { Dictionary, 2021). }\end{array}$ & Leader/Team/Employee \\
\hline 25 & $\begin{array}{l}\text { People-centered } \\
\text { (employees) }\end{array}$ & $\begin{array}{l}\text { "An approach in which people should be } \\
\text { treated as individuals and receive } \\
\text { appropriate and timely care that meets } \\
\text { their needs (DictionarySegen's, 2011)", in } \\
\text { this case, related to employee. }\end{array}$ & Organization \\
\hline 26 & Personal growth & $\begin{array}{l}\text { "Is a process of both understanding } \\
\text { yourself and pushing yourself to reach your } \\
\text { highest potential" (Jackson, 2021) }\end{array}$ & Employee \\
\hline 27 & Proactive attitudes & $\begin{array}{l}\text { "Taking action by causing change and not } \\
\text { only reacting to change when it happens" } \\
\text { (Cambridge English Dictionary, 2021n). }\end{array}$ & Employee \\
\hline 28 & Quality & $\begin{array}{l}\text { "The degree of excellence of something, } \\
\text { often a high degree of it"(Cambridge } \\
\text { English Dictionary, 2021o). }\end{array}$ & Organization \\
\hline 29 & $\begin{array}{l}\text { Questioning (Team } \\
\text { always question what is } \\
\text { being developed/ } \\
\text { restlessness) }\end{array}$ & $\begin{array}{l}\text { "Expressing doubts about the value or } \\
\text { truth of something; showing that you want } \\
\text { an answer about something" (Cambridge } \\
\text { English Dictionary, 2021p). }\end{array}$ & Team/ Employee \\
\hline 30 & $\begin{array}{l}\text { Rapid experimentation } \\
\text { (Split project into steps) }\end{array}$ & $\begin{array}{l}\text { "Rapid experimentation enables teams to } \\
\text { build the minimum amount to test the } \\
\text { most important questions. With this agile } \\
\text { approach to product development, } \\
\text { experiments are launched rapidly to } \\
\text { validate assumptions, test hypotheses and } \\
\text { to discover new ideas (Airfocus, 2020)". }\end{array}$ & Team \\
\hline 31 & Readiness & $\begin{array}{l}\text { "Willingness or a state of being prepared } \\
\text { for something" (Cambridge English } \\
\text { Dictionary, 2021q). }\end{array}$ & Team/ Employee \\
\hline
\end{tabular}




\begin{tabular}{|c|c|c|c|}
\hline $\mathrm{N}^{\mathrm{O}}$ & Cultural Characteristics & Definition & Responsible \\
\hline 32 & Recognition of work & $\begin{array}{l}\text { "Public appreciation for a person's or } \\
\text { group's achievements"(Cambridge English } \\
\text { Dictionary, 2021r). }\end{array}$ & Organization/Leader/Team \\
\hline 33 & Risk Taking & $\begin{array}{l}\text { "The activity of taking risks in order to } \\
\text { start a company, increase profits, } \\
\text { etc."(Cambridge English Dictionary, 2021s). }\end{array}$ & Organization \\
\hline 34 & Personal Autonomy & $\begin{array}{l}\text { "Is the capacity to decide for oneself and } \\
\text { pursue a course of action in one's life, } \\
\text { often regardless of any particular moral } \\
\text { content"(Internet Encyclopedia of } \\
\text { Philosophy, 2021). }\end{array}$ & Employee \\
\hline 35 & Sociability & $\begin{array}{l}\text { "The quality of liking to meet and spend } \\
\text { time with other people" (Cambridge } \\
\text { English Dictionary, 2021t). }\end{array}$ & Employee \\
\hline 36 & Structuring & $\begin{array}{l}\text { "To plan, organize, or arrange the parts of } \\
\text { something"(Cambridge English Dictionary, } \\
\text { 2021u). }\end{array}$ & Organization/Leader \\
\hline 37 & Talent investment & $\begin{array}{l}\text { "The act of putting money, effort, time, } \\
\text { etc. into something to make a profit or get } \\
\text { an advantage" in this case, related "to } \\
\text { people who have a natural ability to be } \\
\text { good at something"(Cambridge English } \\
\text { Dictionary, 20211). }\end{array}$ & Organization/Leader \\
\hline 38 & Team cohesion & $\begin{array}{l}\text { "The strength and extent of interpersonal } \\
\text { connection existing among the members of } \\
\text { a group" (CFI, 2021) }\end{array}$ & Team \\
\hline 39 & Teamwork & $\begin{array}{l}\text { "Employee participation and corporate } \\
\text { commitment to employees" (Rezaei et al., } \\
\text { 2018). }\end{array}$ & Team/Employee \\
\hline 40 & $\begin{array}{l}\text { Trust between members } \\
\text { and leadership }\end{array}$ & $\begin{array}{l}\text { "Belief that you can depend on someone } \\
\text { or something", in this case, related to } \\
\text { members and leadership (Cambridge } \\
\text { English Dictionary, 2021w). }\end{array}$ & Team \\
\hline 41 & Value in people & $\begin{array}{l}\text { "The importance or worth of something } \\
\text { for someone; to consider something } \\
\text { important"(Cambridge English Dictionary, } \\
2021 x) \text {, in this case, related to people. }\end{array}$ & Organization \\
\hline
\end{tabular}

The Figure 4 shows the quantity of characteristics that must be developed by each responsible.

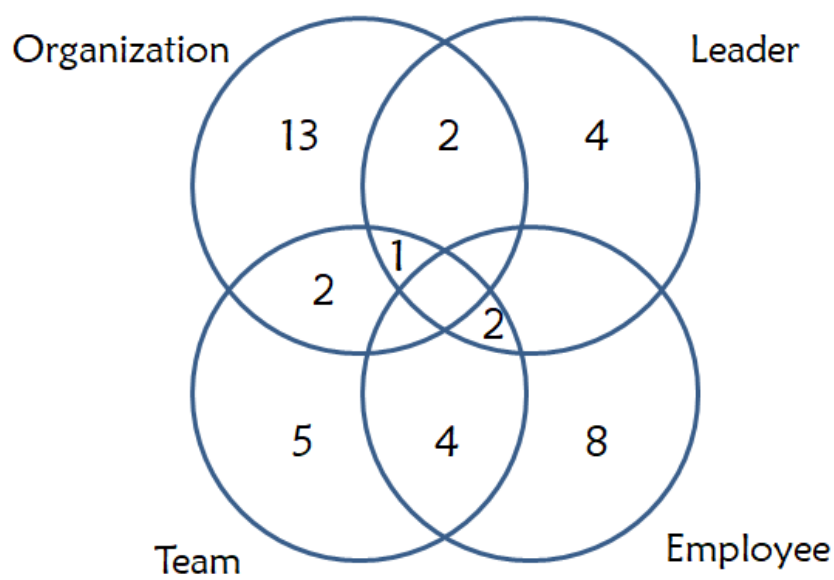

Figure 4: Number of characteristics related to each responsible 


\section{CONCLUSIONS}

To answer the research question "What cultural characteristics/factors affect the adoption of innovative technologies, such as AM?" This work performed a Systematic literature review (SLR) to identify organizational culture characteristics that can provide a path to successfully implement innovative technologies, which will be fundamental to survive throughout industry 4.0. In total, 41 cultural characteristics were selected and summarized. Most people inside organizations usually fears changes. It becomes very important that companies develop some culture characteristics to assist their personnel during changes, helping them to understand how to adapt to new market demands. The incorporation of those characteristics by the organization can encourage innovation and help the implementation of innovative technologies and not only AM. In future work these characteristics will be evaluated by $A M$ experts to determine which of them are most important to be developed. By knowing which cultural characteristics can make companies more susceptible to changes, they can be better prepared to implement AM in an effective way, towards industry 4.0 .

\section{ACKNOWLEDCEMENT}

This study was financed in part by the Coordenação de Aperfeiçoamento de Pessoal de Nivel Superior - Brasil (CAPES) - Finance Code 001. FAPESP 2016/11309-0

\section{REFERENCES}

1. Airfocus. (2020). What Is Rapid Experimentation? Definition and Examples. Retrieved 30 March 2021, from https://airfocus.com/glossary/what-is-rapid-experimentation/

2. Alexe, C. G., \& Alexe, C. M. (2018). Similarities and differentiations at the level of the industries in acquiring an organizational culture in innovation. In Procedia Manufacturing (Vol. 22, pp. 317-324). Elsevier B.V. Retrieved from https://doi.org/10.1016/j.promfg.2018.03.048

3. Alharbi, I. B., Jamil, R., Mahmood, N. H. N., \& Shaharoun, A. M. (2019). Exploring the Relationships Between Organizational Culture, Management Control System and Organizational Innovation. Global Business Review, 097215091987034. Retrieved 3 January 2021 from https://doi.org/10.1177/0972150919870341

4. Ali Taha, V., Sirkova, M., \& Ferencova, M. (2016). THE IMPACT OF ORGANIZATIONAL CULTURE ON CREATIVITY AND INNOVATION. Polish Journal of Management Studies, 14(1), 7-17. Retrieved from https://doi.org/10.17512/pjms.2016.14.1.01

5. Almeida, J. F. (in press) (2021). Adoção de Manufatura Aditiva (MA) para Metais em Empresas: identificação de barreiras e proposta de roteiro para implementação. Universidade de São Paulo.

6. American Society for Testing and Materials. (2010). ASTM F2792-10: standard terminology for additive manufacturing technologies.

7. American Society for Testing and Materials. (2012). ASTM F2792 - 12a: Standard Terminology for Additive Manufacturing Technologies.

8. ASQ. (2021). What is Employee Empowerment? Job Involvement \& Culture | ASQ. Retrieved 29 March 2021, from https://asq.org/quality-resources/employee-empowerment

9. Bendak, S., Shikhli, A. M., \& Abdel-Razek, R. H. (2020). How changing organizational culture can enhance innovation? Development of the innovative culture enhancement framework. Cogent Business and Management, 7(1). Retrieved from https://doi.org/10.1080/23311975.2020.1712125

10. Bercea, O.-B., Lakatos, E.-S., \& Bacali, L. (2019). Comparative Study Regarding Organizational Culture: Nonprofit Organization and Profit-Oriented Organization (pp. 41-52). Retrieved from https://doi.org/10.1007/978-3-319-89872-8 3

11. Biamino, S., Penna, A., Ackelid, U., Sabbadini, S., Tassa, O., Fino, P., ... Badini, C. (2011). Electron beam melting of Ti-48Al-2Cr-2Nb alloy: Microstructure and mechanical properties investigation. Intermetallics, 19(6), 776781. Retrieved from https://doi.org/10.1016/j.intermet.2010.11.017

12. Bland, S., \& Conner, B. (2015). Mapping out the additive manufacturing landscape. Metal Powder Report, 70(3), 115-119. Retrieved from https://doi.org/10.1016/j.mprp.2014.12.052

13. Bourell, D., Kruth, J. P., Leu, M., Levy, G., Rosen, D., Beese, A. M., \& Clare, A. (2017). Materials for additive manufacturing. CIRP Annals, 66(2), 659-681. Retrieved from https://doi.org/10.1016/j.cirp.2017.05.009

14. Cambridge English Dictionary. (2021a). AGGRESSIVENESS. Retrieved 30 March 2021, from https://dictionary.cambridge.org/pt/dicionario/ingles/aggressiveness

15. Cambridge English Dictionary. (2021b). COMMITMENT. Cambridge English Dictionary. Retrieved 29 March 2021 from https://dictionary.cambridge.org/pt/dicionario/ingles/commitment?q=Commitment

16. Cambridge English Dictionary. (2021c). COMMUNICATION. Cambridge English Dictionary. Retrieved 29 March 2021 from https://dictionary.cambridge.org/dictionary/english/communication

17. Cambridge English Dictionary. (2021d). CONNECTION. Retrieved 30 March 2021, from https://dictionary.cambridge.org/pt/dicionario/ingles/connection?q=Connection

18. Cambridge English Dictionary. (2021e). COOPERATION. Cambridge English Dictionary. Retrieved 29 March 2021 from https://dictionary.cambridge.org/pt/dicionario/ingles/cooperation

19. Cambridge English Dictionary. (2021f). CUSTOMER-FOCUSED. Cambridge English Dictionary. Retrieved 29 
March 2021 from https://dictionary.cambridge.org/pt/dicionario/ingles/customer-focused

20. Cambridge English Dictionary. (2021g). DISCIPLINE. Cambridge English Dictionary. Retrieved 29 March 2021 from https://dictionary.cambridge.org/pt/dicionario/ingles/discipline?q=Discipline

21. Cambridge English Dictionary. (2021h). EFFICIENCY. Cambridge English Dictionary. Retrieved 29 March 2021 from https://dictionary.cambridge.org/pt/dicionario/ingles/efficiency?q=Efficiency

22. Cambridge English Dictionary. (2021i). ENCOURAGEMENT. Cambridge English Dictionary. Retrieved 29 March 2021 from https://dictionary.cambridge.org/pt/dicionario/ingles/encouragement?q=Encouragement

23. Cambridge English Dictionary. (2021j). FLEXIBILITY. Cambridge English Dictionary. Retrieved 29 March 2021 from https://dictionary.cambridge.org/pt/dicionario/ingles/flexibility?q=Flexibility

24. Cambridge English Dictionary. (2021k). INNOVATION. Retrieved 30 March 2021, from https://dictionary.cambridge.org/pt/dicionario/ingles/innovation

25. Cambridge English Dictionary. (20211). INVESTMENT. Retrieved 30 March 2021, from https://dictionary.cambridge.org/pt/dicionario/ingles/investment

26. Cambridge English Dictionary. (2021m). MOTIVATION. Cambridge English Dictionary. Retrieved 29 March 2021 from https://dictionary.cambridge.org/pt/dicionario/ingles/motivation?q=Motivation

27. Cambridge English Dictionary. (2021n). PROACTIVE. Cambridge English Dictionary. Retrieved from https://dictionary.cambridge.org/pt/dicionario/ingles/proactive

28. Cambridge English Dictionary. (20210). QUALITY. Cambridge English Dictionary. Retrieved 29 March 2021 from https://dictionary.cambridge.org/pt/dicionario/ingles/quality?q=Quality

29. Cambridge English Dictionary. (2021p). QUESTIONING. Cambridge English Dictionary. Retrieved 29 March 2021 from https://dictionary.cambridge.org/pt/dicionario/ingles/questioning?q=Questioning

30. Cambridge English Dictionary. (2021q). READINESS. Cambridge English Dictionary. Retrieved 29 March 2021 from https://dictionary.cambridge.org/pt/dicionario/ingles/readiness?q=Readiness

31. Cambridge English Dictionary. (2021r). RECOGNITION. Retrieved from https://dictionary.cambridge.org/pt/dicionario/ingles/recognition

32. Cambridge English Dictionary. (2021s). RISK-TAKING. Cambridge English Dictionary. Retrieved from https://dictionary.cambridge.org/pt/dicionario/ingles/risk-taking

33. Cambridge English Dictionary. (2021t). SOCIABILITY. Cambridge English Dictionary. Retrieved 29 March 2021 from https://dictionary.cambridge.org/pt/dicionario/ingles/sociability?q=Sociability

34. Cambridge English Dictionary. (2021u). STRUTURING. Cambridge English Dictionary. Retrieved from https://dictionary.cambridge.org/pt/dicionario/ingles/structuring

35. Cambridge English Dictionary. (2021v). SUPPORT. Retrieved 30 March 2021, from https://dictionary.cambridge.org/pt/dicionario/ingles/support

36. Cambridge English Dictionary. (2021w). TRUST. Retrieved 30 March 2021, from https://dictionary.cambridge.org/pt/dicionario/ingles/trust

37. Cambridge English Dictionary. (2021x). VALUE. Retrieved 30 March 2021, from https://dictionary.cambridge.org/pt/dicionario/ingles/value

38. Cameron, K. S.; Quinn, R. E. (1999). Diagnosing and Changing Organizational Culture: Based on the Competing Values Framework. 1st Edition, MA: Addison Wesley.

39. Cameron, K., Quinn, R. E., DeGraff, J., \& Thakor, A. (2006). Competing values leadership: Creating value in organizations.

40. Carro-Suárez, J., Sarmiento-Paredes, S., \& Rosano-Ortega, G. (2017). Organizational culture and its influence in business sustainability. The importance of culture in corporate sustainability. Estudios Gerenciales, 33(145), 352365. Retrieved 4 January 2021 from https://doi.org/10.1016/j.estger.2017.11.006

41. Casati, R., Lemke, J., \& Vedani, M. (2016). Microstructure and Fracture Behavior of 316L Austenitic Stainless Steel Produced by Selective Laser Melting. Journal of Materials Science and Technology, 32(8), 738-744. Retrieved from https://doi.org/10.1016/j.jmst.2016.06.016

42. CFI. (2021). Team Cohesion - Overview, Examples, Strategies for Team Bonding. Retrieved 29 March 2021 , from https://corporatefinanceinstitute.com/resources/careers/soft-skills/team-cohesion/

43. Chang, W. J., Liao, S. H., \& Wu, T. Te. (2017). Relationships among organizational culture, knowledge sharing, and innovation capability: A case of the automobile industry in Taiwan. Knowledge Management Research and Practice, 15(3), 471-490. Retrieved from https://doi.org/10.1057/s41275-016-0042-6

44. Chatman, J. A., \& O'Reilly, C. A. (2016). Paradigm lost: Reinvigorating the study of organizational culture. Research in Organizational Behavior, 36, 199-224. Retrieved from https://doi.org/10.1016/j.riob.2016.11.004

45. Chatterjee, A., Pereira, A., \& Bates, R. (2018). Impact of individual perception of organizational culture on the learning transfer environment. International Journal of Training and Development, 22(1), 15-33. Retrieved from https://doi.org/10.1111/ijtd.12116

46. Cooke, R. A.; Lafferty, J. C. (1995). Organizational culture inventory. Plymouth, MI: Human Synergistic International,.

47. Cui, Y., Liu, Y., \& Mou, J. (2018). Bibliometric analysis of organisational culture using CiteSpace. South African Journal of Economic and Management Sciences, 21(1). Retrieved from https://doi.org/10.4102/sajems.v21i1.2030 
48. DebRoy, T., Wei, H. L., Zuback, J. S., Mukherjee, T., Elmer, J. W., Milewski, J. O., ... Zhang, W. (2018). Additive manufacturing of metallic components - Process, structure and properties. Progress in Materials Science. Retrieved from https://doi.org/10.1016/j.pmatsci.2017.10.001

49. DictionarySegen's. (2011). people-centered. Retrieved 30 March 2021, from https://medicaldictionary.thefreedictionary.com/people-centered+care

50. Dietrich, D. M., Kenworthy, M., \& Cudney, E. A. (2019). Additive Manufacturing Change Management. Additive Manufacturing Change Management. Boca Raton: Taylor \& Francis, 2019. | Series: Continuous: CRC Press. Retrieved from https://doi.org/10.1201/9780429465246

51. Maier, D., Bumbac, R., Ilie, C., \& Maier, A. (2019). Organizational Culture - Prerequisite of an Innovative Behavior in Business. In International Business Information Management Association (IBIMA). Retrieved 3 January 2021 from https://ibima.org/accepted-paper/organizational-culture-prerequisite-of-an-innovativebehavior-in-business/

52. Felipe, C. M., Roldán, J. L., \& Leal-Rodríguez, A. L. (2017). Impact of organizational culture values on organizational agility. Sustainability (Switzerland), 9(12). Retrieved from https://doi.org/10.3390/su9122354

53. Garvin, D. A. (1993). Building a Learning Organization. Harvard Business Review, July-Augus.

54. Gaytan, S. M., Murr, L. E., Martinez, E., Martinez, J. L., MacHado, B. I., Ramirez, D. A., ... Wicker, R. B. (2010). Comparison of microstructures and mechanical properties for solid and mesh cobalt-base alloy prototypes fabricated by electron beam melting. Metallurgical and Materials Transactions A: Physical Metallurgy and Materials Science, 41(12), 3216-3227. Retrieved from https://doi.org/10.1007/s11661-010-0388-y

55. Gibson, I., Rosen, D., \& Stucker, B. (2015). Additive manufacturing technologies: 3D printing, rapid prototyping, and direct digital manufacturing, second edition. Additive Manufacturing Technologies: 3D Printing, Rapid Prototyping, and Direct Digital Manufacturing, Second Edition. Springer New York. Retrieved from https://doi.org/10.1007/978-1-4939-2113-3

56. Gu, D. D., Meiners, W., Wissenbach, K., \& Poprawe, R. (2012). Laser additive manufacturing of metallic components: Materials, processes and mechanisms. International Materials Reviews, 57(3), 133-164. Retrieved from https://doi.org/10.1179/1743280411Y.0000000014

57. Hock, M., Clauss, T., \& Schulz, E. (2016). The impact of organizational culture on a firm's capability to innovate the business model. $R$ and $D$ Management, 46(3), 433-450. Retrieved from https://doi.org/10.1111/radm.12153

58. Hofstede, G. (2001). Culture's Consequences: Comparing Values, Behaviors, Institutions, and Organizations Across Nations. Culture's Consequences: Comparing Values, Behaviors, Institutions, and Organizations Across Nations. Retrieved 29 March 2021 from https://digitalcommons.usu.edu/unf_research/53

59. Internet Encyclopedia of Philosophy. (2021). Autonomy. Internet Encyclopedia of Philosophy.

60. Jackson, R. (2021). The Importance of Self-Improvement and Personal Growth | Top Practices. Retrieved 29 March 2021, from https://www.toppractices.com/blog/the-importance-of-self-improvement-and-personalgrowth.cfm

61. Khairallah, S. A., Anderson, A. T., Rubenchik, A. M., \& King, W. E. (2017). Laser powder-bed fusion additive manufacturing: Physics of complex melt flow and formation mechanisms of pores, spatter, and denudation zones. In Additive Manufacturing Handbook: Product Development for the Defense Industry (pp. 613-628). Retrieved from https://doi.org/10.1201/9781315119106

62. Kotter, J. P. (1996). Leading Change. Harvard Business Review Press.

63. Krupskyi, O. P., \& Kuzmytska, Y. (2020). Organizational Culture and Business Strategy: Connection and Role for A Company Survival. Central European Business Review, 9(4), 1-26. Retrieved from https://doi.org/10.18267/j.cebr.241

64. Leal-Rodríguez, A. L., Eldridge, S., Ariza-Montes, J. A., \& Morales-Fernández, E. J. (2019). Understanding How Organizational Culture Typology Relates to Organizational Unlearning and Innovation Capabilities. Journal of the Knowledge Economy, 10(4), 1497-1514. Retrieved from https://doi.org/10.1007/s13132-015-0344-6

65. Lee, W. L., Chong, A. L., \& Ramayah, T. (2018). Organizational culture and performance of Malaysian manufacturing firms. International Journal of ADVANCED AND APPLIED SCIENCES, 5(12), 59-66. Retrieved from https://doi.org/10.21833/ijaas.2018.12.008

66. Li, J., Zhou, X., Brochu, M., Provatas, N., \& Zhao, Y. F. (2020). Solidification microstructure simulation of Ti$6 \mathrm{Al}-4 \mathrm{~V}$ in metal additive manufacturing: A review. Additive Manufacturing. Retrieved from https://doi.org/10.1016/j.addma.2019.100989

67. Liao, S. H., Hu, D. C., Chen, C. C., \& Lin, Y. L. (2015). Comparison of competing models and multi-group analysis of organizational culture, knowledge transfer, and innovation capability: An empirical study of the Taiwan semiconductor industry. Knowledge Management Research and Practice, 13(3), 248-260. Retrieved from https://doi.org/10.1057/kmrp.2013.46

68. Mardiana, S., \& Tjakratmadja, J. H. (2019). Exploring the linkage between knowledge management and organizational culture: A study of literature. Journal of Advanced Research in Dynamical and Control Systems, 11(3 Special Issue), 1003-1012.

69. McInnes, M. D. F., Moher, D., Thombs, B. D., McGrath, T. A., Bossuyt, P. M., Clifford, T., ... Willis, B. H. (2018). Preferred Reporting Items for a Systematic Review and Meta-analysis of Diagnostic Test Accuracy Studies The PRISMA-DTA Statement. JAMA - Journal of the American Medical Association, 319(4), 388-396. Retrieved 
29 March 2021 from https://doi.org/10.1001/jama.2017.19163

70. Miletić, S., Stanojević, Š. Z., Jovanović, I., Radivojević, M., \& Conić, V. (2020). AHP analysis of organizational culture in textile companies in Serbia. Industria Textila, 71(2), 124-131. Retrieved from https://doi.org/10.35530/IT.071.02.1588

71. Mohelska, H., \& Sokolova, M. (2018). Management approaches for industry $4.0-$ The organizational culture perspective. Technological and Economic Development of Economy, 24(6), 2225-2240. Retrieved from https://doi.org/10.3846/tede.2018.6397

72. Naranjo-Valencia, J. C., Jimenez-Jimenez, D., \& Sanz-Valle, R. (2017a). Impact of Organisational Culture on New Product Success: an Empirical Study of Spanish Firms. European Management Review, 14(4), 377-390. Retrieved from https://doi.org/10.1111/emre.12116

73. Naranjo-Valencia, J. C., Jimenez-Jimenez, D., \& Sanz-Valle, R. (2017b). Organizational culture and radical innovation: Does innovative behavior mediate this relationship? Creativity and Innovation Management, 26(4), 407-417. Retrieved 3 January 2021 from https://doi.org/10.1111/caim.12236

74. Ngo, T. D., Kashani, A., Imbalzano, G., Nguyen, K. T. Q., \& Hui, D. (2018). Additive manufacturing (3D printing): A review of materials, methods, applications and challenges. Composites Part B: Engineering. Retrieved from https://doi.org/10.1016/j.compositesb.2018.02.012

75. O’Reilly, C. A., Chatman, J., \& Caldwell, D. F. (1991). PEOPLE AND ORGANIZATIONAL CULTURE: A PROFILE COMPARISON APPROACH TO ASSESSING PERSON-ORGANIZATION FIT. Academy of Management Journal, 34(3), 487-516. Retrieved from https://doi.org/10.5465/256404

76. Oxford Advanced Learner's Dictionary. (2021). Openness noun - Definition, pictures, pronunciation and usage notes. $\quad$ Retrieved $30 \quad$ March $\quad 2021$, from https://www.oxfordlearnersdictionaries.com/definition/english/openness

77. Parolin, S. R., Bonfim, L. R. C., Segatto, A. P., \& Espindola, T. (2020). Organizational culture for cooperation in technological innovation between research institutes and firms. Journal of Technology Management and Innovation, 15(2), 23-40. Retrieved from https://doi.org/10.4067/s0718-27242020000200024

78. Pietruszka-Ortyl, A. (2019). THE IMPACT OF ORGANIZATIONAL CULTURE FOR COMPANY'S INNOVATION STRATEGY. Marketing and Management of Innovations, (3), 178-192. Retrieved from https://doi.org/10.21272/mmi.2019.3-14

79. Quinn, R. E., \& Rohrbaugh, J. (1983). SPATIAL MODEL OF EFFECTIVENESS CRITERIA: TOWARDS A COMPETING VALUES APPROACH TO ORGANIZATIONAL ANALYSIS. Management Science, 29(3), 363-377. Retrieved 29 March 2021 from https://doi.org/10.1287/mnsc.29.3.363

80. Ramiro, M. (2018). Why should your teams be multifunctional? - Paradigma. Retrieved 29 March 2021, from https://en.paradigmadigital.com/techbiz/why-should-your-teams-be-multifunctional/

81. Rezaei, A., Allameh, S. M., \& Ansari, R. (2018). Effect of organisational culture and organisational learning on organisational innovation: an empirical investigation. International Journal of Productivity and Quality Management, 23(3), 307. Retrieved 3 January 2021 from https://doi.org/10.1504/IJPQM.2018.089803

82. Saunders, M. (2018). Additive impact part \#1 - how Additive Manufacturing could disrupt your market.

83. Saunders, M. (2019). Additive impact part \#2 - how AM could disrupt your market.

84. Savolainen, J., \& Collan, M. (2020). How Additive Manufacturing Technology Changes Business Models? Review of Literature. Additive Manufacturing, 32, 101070. Retrieved from https://doi.org/10.1016/j.addma.2020.101070

85. Schein, E. (1984). Coming to a new awareness of organizational culture. Sloan Management Review, Winter, 3-16.

86. Shahzad, F., Xiu, G. Y., \& Shahbaz, M. (2017). Organizational culture and innovation performance in Pakistan's software industry. Technology in Society, 51, 66-73. Retrieved from https://doi.org/10.1016/j.techsoc.2017.08.002

87. Sieber, M. R. (2019). The role of organizational culture for information technology management in digitalization. In Conference Innovation Management, Entrepreneurship and Sustainability (IMES 2019) (pp. 805-819). Vysoká škola ekonomická v Praze. Retrieved 22 January 2021 from https://www.ceeol.com/search/chapter-detail?id=785541

88. Singh, S., Ramakrishna, S., \& Singh, R. (2017). Material issues in additive manufacturing: A review. Journal of Manufacturing Processes, 25, 185-200. Retrieved from https://doi.org/10.1016/j.jmapro.2016.11.006

89. Stacho, Z., Potkány, M., Stachová, K., \& Marcineková, K. (2016). The organizational culture as a support of innovation processes' management: A case study. International Journal for Quality Research, 10(4), 769-784. Retrieved from https://doi.org/10.18421/IJQR10.04-08

90. Stewart, L. A., Clarke, M., Rovers, M., Riley, R. D., Simmonds, M., Stewart, G., \& Tierney, J. F. (2015, April 28). Preferred reporting items for a systematic review and meta-analysis of individual participant data: The PRISMA-IPD statement. JAMA - Journal of the American Medical Association. American Medical Association. Retrieved 29 March 2021 from https://doi.org/10.1001/jama.2015.3656

91. Szczepańska-Woszczyna, K. (2015). Leadership and Organizational Culture as the Normative Influence of Top Management on Employee's Behaviour in the Innovation Process. In Procedia Economics and Finance (Vol. 34, pp. 396-402). Elsevier BV. Retrieved from https://doi.org/10.1016/s2212-5671(15)01646-9 
92. Tang, L. L., \& Yeh, Y. L. (2015). Effect of organizational culture, leadership style, and organizational learning on organizational innovation in the public sector. Journal of Quality, 22(5), 461-481. Retrieved from https://doi.org/10.6220/joq.2015.22(5).06

93. Vaidya, S., Ambad, P., \& Bhosle, S. (2018). Industry 4.0 - A Glimpse. Procedia Manufacturing, 20, $233-238$. Retrieved from https://doi.org/10.1016/j.promfg.2018.02.034

94. Valamis. (2019). What is continuous learning? Its Importance \& Benefits. Retrieved 29 March 2021, from https://www.valamis.com/hub/continuous-learning

95. Vargas Halabi, T., Mora Esquivel, R., \& Ortiz Acuña, C. (2015). Cultura organizativa e innovación: un análisis temático en empresas de Costa Rica (Organizational culture and innovation: a thematic analysis in Costa Rica's firms). TEC Empresarial, 9(2), 7. Retrieved from https://doi.org/10.18845/te.v9i2.2358

96. Vnoučková, L., \& Urbancová, H. (2020). Setting organisational culture to develop potential and innovativeness. Quality Innovation Prosperity, 24(1), 54-68. Retrieved from https://doi.org/10.12776/QIP.V24I1.1346

97. Vrancken, B., Thijs, L., Kruth, J. P., \& Van Humbeeck, J. (2012). Heat treatment of Ti6Al4V produced by Selective Laser Melting: Microstructure and mechanical properties. Journal of Alloys and Compounds, 541, 177185. Retrieved from https://doi.org/10.1016/j.jallcom.2012.07.022

98. Wu, L. F., Huang, I. C., Huang, W. C., \& Du, P. L. (2019). Aligning organizational culture and operations strategy to improve innovation outcomes: An integrated perspective in organizational management. Journal of Organizational Change Management, 32(2), 224-250. Retrieved from https://doi.org/10.1108/JOCM-03-20180073

99. Yu, O., \& Shih, R. (2018). Developing an innovative organizational culture: A people-centered and valuefocused approach with case studies. In PICMET 2018 - Portland International Conference on Management of Engineering and Technology: Managing Technological Entrepreneurship: The Engine for Economic Growth, Proceedings. Institute of Electrical and Electronics Engineers Inc. Retrieved from https://doi.org/10.23919/PICMET.2018.8481945

100. Ziaei Nafchi, M., Mohelská, H., \& Maresova, P. (2019). Industry 4.0: The Organizational Culture Perspective. In Hradec Economic Days 2019 (pp. 575-580). University of Hradec Kralove. Retrieved from https://doi.org/10.36689/uhk/hed/2019-02-058 